\title{
PEMBERDAYAAN KELOMPOK PETANI JAMUR TIRAM DESA DUYUNG KECAMATAN TRAWAS KABUPATEN MOJOKERTO
}

\author{
Muhammad Priyono Tri Sulistyanto'), Kurriawan Budi Pranata'), \\ Solikhan ${ }^{1)}$, Muhammad Ghufron' ${ }^{2)}$ \\ ${ }^{1)}$ Fakultas Sains dan Teknologi Universitas Kanjuruhan Malang \\ ${ }^{2)}$ Fakultas Matematika dan Ilmu Pengetahuan Alam Universitas Brawijaya \\ kurriawan@unikama.ac.id
}

DOI : 10.31604/j.martabe.v1i3.108-116

\begin{abstract}
Community service activities have been carried out in Duyung Village, Trawas Subdistrict, Mojokerto Regency, East Java, with partners of farmer groups, cultivating oyster mushrooms. The purpose of this service activity is the transfer of mechanical technology to reduce the potential for crop failure and increase the capacity of oyster mushroom production in the Trawas sub-district. The technology transfer is applied in the form of making a steamer for baglog sterilization with a constant temperature control method in the steamer machine room. Temperature monitoring uses an analog thermocouple sensor, while temperature settings are carried out conventionally. The implementation method of this program consists of four stages. 1) Socialization and coordination of activities with partners 2) Mechanical technology survey activities regarding the need for supporting equipment in making steamer machines 3) Training and demonstration of the use of steamer machines 4) Evaluation and monitoring framework for machine usage effectiveness. The results of the community service activities include a) Shortening the process of making baglog which originally took 15 hours now to 8 hours. b) Baglog production capacity increases in line with the increase in oyster mushroom production and increase the value of assets and turnover to partners. c) Reduce fears of potential harvest failure due to baglog making process, so that it is expected to bring new entrepreneurs about oyster mushroom cultivation.
\end{abstract}

Keywords: Farmers Group, Oyster Mushrooms, A Village Of Mermaids.

\begin{abstract}
Abstrak
Telah dilakukan kegiatan pengabdian masyarakat di Desa Duyung Kecamatan trawas Kabupaten Mojokerto Jawa Timur dengan mitra kelompok petani budidaya jamur tiram. Tujuan dari kegiatan pengabdian ini berupa transfer teknologi mekanik guna mengurangi potensi gagal panen dan meningkatkan kapasitas produksi jamur tiram di wilayah kecamatan Trawas. Transfer teknologi yang diterapkan berupa pembuatan mesin steamer untuk sterilisasi baglog dengan metode pengaturan suhu konstan di dalam ruangan mesin steamer. Monitoring suhu menggunakan sensor termokopel analog, sedangkan pengaturan suhu dilakukan secara konvensional. Metode pelaksanaan dari program ini terdiri dari empat tahap meliputi. 1) Sosialisai dan koordinasi kegiatan dengan pihak mitra 2) Kegiatan survey teknologi mekanik mengenai kebutuhan alat penunjang dalam pembuatan mesin steamer 3) Pelatihan dan demonstrasi penggunaan mesin steamer 4) Evaluasi dan kerangka monitoring efektifitas penggunaan mesin. Hasil
\end{abstract}


dari kegiatan pengabdian masyarakat ini meliputi a) Mempersingkat proses pembuatan baglog yang semula membutuhkan waktu 15 jam sekarang menjadi 8 jam. b) Kapasitas produksi baglog meningkat yang sejalan dengan meningkatnya produksi jamur tiram serta menambah nilai asset dan omzet kepada pihak mitra c) Mengurangi kekhawatiran potensi gagal panen akibat proses pembuatan baglog, Sehingga diharapkan dapat memunculkan wirausahawan baru tentang budidaya jamur tiram.

Kata kunci: Kelompok Tani, Jamur Tiram, Desa Duyung.

\section{PENDAHULUAN}

Budidaya jamur tiram belum banyak dikembangkan di Indonesia, baik sebagai pemenuhan kebutuhan konsumsi makanan sayur mayur seharihari maupun sebagai peluang usaha (Sutarja, 2010). Padahal jamur tiram merupakan produksi pangan holtikultura berupa jenis sayuran yang memiliki khasiat kesehatatan dan nilai gizi tinggi (Suriawiria, 2002).

Menurut (Sucipto, 2015), peluang usaha agribisnis dalam bidang jamur tiram mempunyai potensi yang cukub besar, karena peluang usaha ini tidak tergantung pada kondisi musim, tidak membutuhkan lahan yang luas, penempatan jamur dapat disusun secara bertingkat, teknis budidaya dalam kondisi ruangan yang harus mempunyai syarat suhu dan kelembapan tertentu. Namun jika kondisi ruangan kurang lembab atau kekurangan air, kelembapan dapat diatur dengan melakukan penyemprotan kedalam sekitar ruangan. Jamur tiram memiliki nilai kandungan protein yang tinggi seperti yang ditunjukkan pada Tabel 1 .

Tabel 1 menunjukkan keunggulan kelayakan konsumsi jamur tiram sebagai alternatif penunjang gizi produk pangan nasional. Namun, produksi jamur tiram di wilayah jawa timur pada tahun 2015 mencapai 7.909.278 kuintal (Jenisa, 2018), hasil ini tidak sebanding jika produksi jamur tiram diolah, dilibatkan dengan potensi wisata Mojokerto, maupun penyerapan tenaga kerja yang berada diwilayah kabupaten Mojokerto. Jangankan pemenuhan kebutuhan pariwisata maupun konsumsi sehari-hari, bahkan setingkat pemenuhan kebutuhan gizi diwilayah kabupaten mojokerto yang berjumlah penduduk 1.138.262 jiwa masih belum cukup (Penduduk Kabupaten Mojokerto, 2017).

Tabel 1: Perbandingan gizi jamur tiram dengan makanan lain.

\begin{tabular}{cccc}
\hline Bahan Pangan & $\begin{array}{c}\text { Protein } \\
(\boldsymbol{\%})\end{array}$ & $\begin{array}{c}\text { Lemak } \\
(\mathbf{\%})\end{array}$ & $\begin{array}{c}\text { Karbohidrat } \\
(\mathbf{\%})\end{array}$ \\
\hline Jamur Tiram & 27,00 & 1,60 & 58,00 \\
Daging Sapi & 21,00 & 5,50 & 0,50 \\
Bayam & 0,00 & 2,20 & 1,70 \\
Kentang & 2,00 & 0,00 & 20,90 \\
Kubis & 1,50 & 0,10 & 4,20 \\
Seledri & 0,00 & 1,30 & 0,20 \\
Buncis & 0,00 & 2,40 & 0,20 \\
\hline
\end{tabular}

Sumber : Parjimo (2007). 
Muhammad Priyono Tri Sulistyanto, dkk. Pemberdayaan Kelompok Petani...

Padahal Kabupaten Mojokerto telah memetakan salah satu potensi pariwisata berada di Kecamatan Trawas. erbagai macam sector wisata yang dikembangkan di wilayah Trawas meliputi wisata kuliner, pendakian, agrowisata, dan berbagai macam fasiltas penginapan yang tersedia seperti villa, hotel maupun tempat bumi perkemahan dan outbond (Perda No. 8 RPJMD Mojokerto, 2011).

Pada sektor bidang agrowisata terdapat wahana kebun durian yang diterapkan sebagai wisata petik durian yaitu Duyung Trawas Hill. Wisata tersebut berlokasi di Desa Duyung Kecamatan Trawas Kabupaten Mojokerto. Bertepatan dengan lokasi tersebut, terdapat kelompok petani budidaya jamur tiram yang dikelola oleh Bapak Wardoyo selaku ketua kelompok. Ironisnya, hasil produksi petani jamur tiram di lingkungan Kecamatan Trawas khusunya di Desa Duyung tidak pernah dilibatkan didalam sektor pariwisata, terbengkalai dan tidak dikelola dengan baik. Padahal dari kebutuhan bahan baku serbuk gergaji kayu sebagai pembuatan baglog sangat melimpah. Karena Trawas merupakan daerah yang dikelilingi hutan tropis yang masih terjaga produktifitas penghasil kayu.

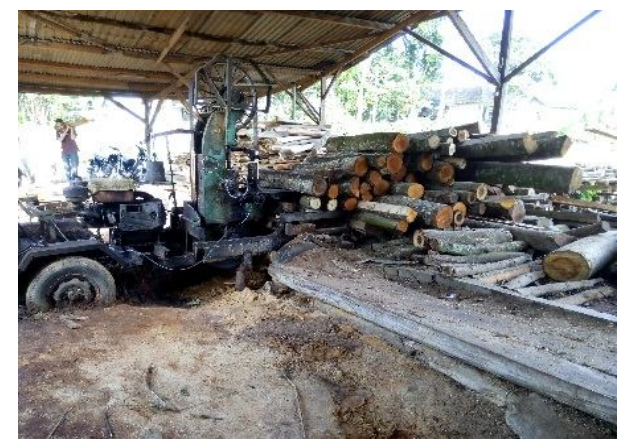

Gambar 1: Melimpahnya serbuk gergaji kayu disekitar Desa Duyung
Melimpahnya bahan baku pembuatan baglog yang digunakan sebagai media tanam pembibitan jamur tiram. Hanya 5\% yang berani untuk berwirausaha sebagai petani jamur dengan mengolah serbuk gergaji kayu menjadi baglog media tanam dan tumbuh kembang jamur tiram. Namun keberanian itu tidak pernah ditiru maupun dicontoh bagi warga sekitar di Desa Duyung. Karena selama ini warga masih berasumsi usaha budidaya jamur tiram terlalu beresiko dan sering terjadi kerugian akibat gagal panen.

Berdasarkan anlisis dan kunjungan tim pengabdi ke tempat mitra, sering terjadinya gagal panen tersebut diakibatkan pada saat proses pembuatan baglog dengan menggunakan mesin steamer yang jauh dari sentuhan teknologi. Keberadaan mesin steamer ini sangat berperan penting dalam proses sterilisasi baglog guna meningkatkan produktifitas, efisiensi waktu dan kapasitas produksi jamur tiram. Menurut (Prana $d k k$, 2018) pada hasil kegiatan pengabdian masyarakat sebelumnya, salah satu solusi dalam peningkatan efisiensi waktu proses produksi dan produktifitas produk yaitu menggunakan alih ilmu transfer teknologi mekanik. Sehingga dalam serangkaian kegiatan pengabdian ini telah dilakukan solusi teknis berupa pembuatan mesin steamer untuk menunjang proses produksi baglog jamur.

Kegiatan pengabdian masyrakat yang ditujukan kepada mitra kelompok petani budidaya jamur tiram ini berfokus pada perbaikan tata nilai ilmu pengetahuan dan perbaikan proses produksi yang meliputi: 1) Pemahaman teknologi dalam proses sterilisasi baglog jamur 2) Kesadaran pentingnya keselamatan kerja pada saat proses produksi dilakukan 3) Perbaikan lamanya rentang waktu proses produksi 
baglog dan 4) Peningkatan kuantitas produksi baglog guna menambah nilai ekonomis dan diharapkan dapat memancing wirausaha baru dalam bidang budidaya jamur tiram.

\section{METODE PELAKSANAAN}

Metode pelaksanaan kegiatan mengacu pada analisis permasalah yang dihadapi kelompok petani budidaya jamur tiram di Desa Duyung. Adapun analisis permasalahan tersebut meliputi:

1) Minimnya pengetahuan teknologi pada saat proses sterilisasi baglog jamur.

2) Rendahnya pemahaman kesadaran akan keselamatan kerja pada saat proses sterilisasi baglog.

3) Proses sterilisasi baglog telah membutuhkan waktu yang cukup lama.

4) Rendahnya kuantitas dan kapasitas produksi jamur tiram akibat kegagalan dalam proses seterilisasi baglog, kondisi tersebut berlanjut hingga kegagalan saat panen raya.

Permasalahan yang telah diuraikan diatas merupakan ujung dari persepsi umum warga Desa Duyung bahwa membudidayakan jamur tiram kurang menghasilkan, sering terjadinya gagal panen dan teralalu berisiko mengalami kerugian dalam hal biaya produksi, waktu dan keselamatan kerja.

Berdasarkan uraian analisis masalah diatas, telah dilakukan metode pendekatan pelaksanaan kegiatan dalam menyelesaikan permasalahan mitra meliputi:

1) Pembuatan mesin sterilisasi baglog jamur, beserta kegiatan pelatihan dan demonstrasi plot (DEMPLOT) cara pengunaan mesin.

2) Pemasangan sensor suhu pada mesin steamer agar pengguna bisa memonitoring suhu ruangan mesin guna menghindari kecelakaan kerja akibat ledakan mesin steamer sebelumnya, karena suhu dalam ruangan mesin yang tidak terkendali.

3) Mempersingkat proses sterilisasi baglog dengan cara mendesain ruang pengapian mesin menggunakan bahan yang mudah menghantarkan panas denga cepat, sedangkan ruang pengapian di desain dwi fungsi bahan pengapian yaitu jika bahan pengapian menggunakan gas elpiji atau kayu bakar.

4) Peningkatan kuantitas dan kapasitas produktifitas jamur menggunakan cara memperbesar kapsitas ruang sterilisasi baglog jamur menjadi 5 kali lipat dari mesin sebelum dilaksanakan kegiatan pengabdian.

5) Melakukan kegiatan evaluasi program dan kerangka monitoring program terhadap efektifitas keberfungsian mesin steamer yang sudah dibuat.

\section{HASIL DAN PEMBAHASAN}

Hasil kegiatan pengabdian
masyarakat yang telah dilakukan
mengacu pada setiap point
permasalahan yang dialami mitra.
Berdasarkan uraian permasalahan
diatas, terdapat empat point
permasalahan yang mengakibatkan
produktifitas jamur tiram di Desa
Duyung tidak dapat berkembang.
Permasalahan point pertama
keberadaan mesin steamer yang jauh
dari sentuhan teknologi seperti yang
ditunjukkan pada Gambar 2.
Pada Gambar 2 menunjukkan
mesin steamer sebelum dilakukan
kegiatan program pengabdian
masyarakat. Mesin tersebut berkapasitas
100 baglog, terbuat dari drum bekas
yang bagian ujung drum ditutup plastic
guna mengisolasi derajat suhu secara
konstan tanpa adanya monitoring suhu
yang akurat, melainkan hanya perkiraan


perlakuan sentuhan tangan manusia. Tentunya hal ini sangat tidak efektif, saat terjadi penguapan udara, plastic mengalami pemuaian hingga menggelembung tak terkendali terkadang sampai timbul bunyi ledakan. Ledakan mesin tersebut hingga terdengar warga sekitar proses produksi baglog. Hal ini yang menyebabkan warga sekitar Desa Duyung enggan untuk berwirausaha dalam bidang budidaya jamur. Akibat ledakan tersebut, mesin steamer mempunyai lubang yang cukup besar yang memungkinkan udara dari luar mesin bisa masuk kedalam baglog untuk mengkontaminasi bibit jamur. Pada akhirnya baglog jamur menjadi rusak tidak dapat dipakai dan proses produksi baglog dihentikan malah beralih membenahi mesin steamer.

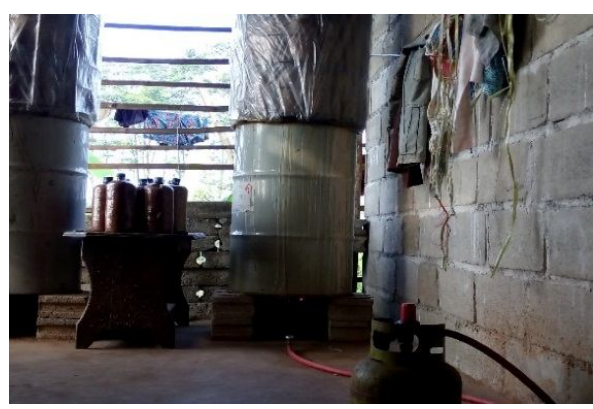

Gambar 2: Keadaan mesin steamer sebelum dilakukan pengabdian masyarakat.

Sebelum dilakukan proses rancang bangun mesin steamer, tim pengabdi melakukan kegiatan koordinasi dengan pihak mitra seperti yang ditunjukkan pada Gambar 3.

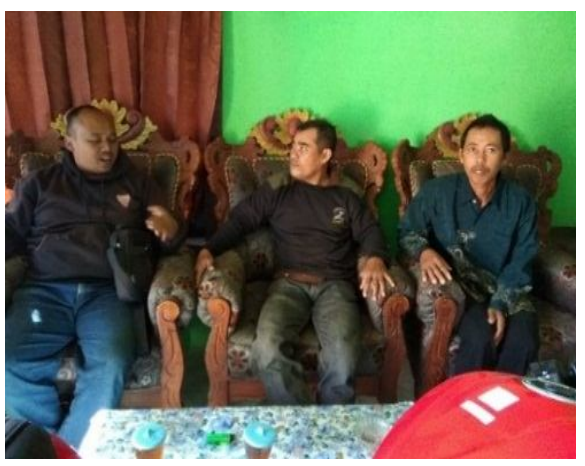

Gambar 3: Sharing dan diskusi.

Gambar 3, kegiatan ini bertujuan untuk mencari kesepakatan rancangan desain dan menganalisis kebutuhan saat proses pembuatan mesin Steamer. Kegiatan ini dilakukan sehari penuh dengan dilanjutkan survey kebutuhan pengadaan teknologi mekanik di sekitar pasar besi kota Pandaan. Hasil kegiatan survey tersebut menghasilkan pembelian alat dan bahan yang menunjang dalam proses pembuatan mesin Steamer.

Tindak lanjut hasil kegiatan survey alat dan bahan tersebut telah didapatkan lokasi pembuatan mesin steamer dan segera dilakukan proses perakitan mesin sesuai dengan kesepakatan desain dengan pihak mitra. Hasil perakitan dari desain yang telah disepakati dengan pihak mitra seperti yang ditunjukkan pada Gambar 4.

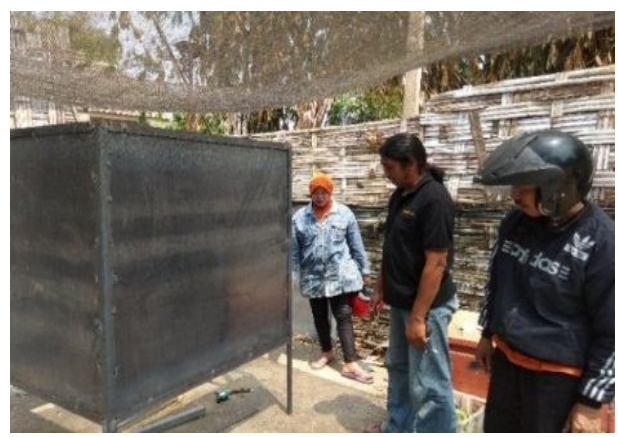

Gambar 4: Perakitan mesin Steamer masih dalam progress $50 \%$. 
Gambar 4, proses perakitan mesin steamer pada tahap progress 50 persen pengerjaan. Mengacu permasalahan poin dua yaitu rendahnya pemahaman dan kesadaran tentang keselamatan kerja, telah didapatkan hasil solusi teknis bahwa mesin tersebut dilengkapi dengan sensor monitoring suhu secara analog. Suhu yang terukur adalah bagian dalam ruangan mesin yang dapat dimonitoring pada bagian luar mesin pada posisi sebelah kiri pintu mesin seperti yang ditunjukkan pada Gambar 6. Tujuan adanya pemasangan sensor suhu ini diharapkan para kelompok petani budidaya jamur tiram agar selalu tetap waspada dan penuh kehati-hatian pada saat sterilisasi baglog pada suhu tinggi. Kerap kali mesin yang digunakan sebelum adanya kegiatan pengabdian ini terjadi ledakan, hal ini disebabkan pada saat suhu ruangan mesin mencapai suhu tinggi, kontrol dan monitoring suhu hanya perkiraan perlakuan sentuhan tangan manusia.

Permasalahan poin tiga yaitu lamanya waktu proses sterilisasi baglog. Sebelum adanya kegitan pengabdian ini mesin yang digunakan seperti yang ditunjukka pada Gambar 2. Mesin tersebut terbuat dari drum bekas yang terbuat dari bahan plat seng tipis yang dibengkokkan menyerupai bentuk silinder berongga. Bahan seng ini bersifat sangat korosif dan mudah memuai jika diterapkan pada perlakuan pemanasan suhu tinggi. Karena mudah memuai dan korosif, dapat dipastikan mesin steamer Gambar 2 jika dipergunakan secara terus menerus berakibat mengalami cacat retakan. Sehingga bagian permukaan mesin terdapat lubang yang berpotensi merusak proses sterilisasi baglog. Gambar 2. Selain itu, bagian penutup ujung mesin menggunakan plastic untuk mengisolasi uap udara panas. Hal inilah yang menjadi penyebab lamanya waktu proses sterilisasi baglog dan berpotensi terjadi ledakan mesin karena kurang memperhitungkan efisiensi penyimpanan panas pada mesin steamer.

Hasil analisis permasalahan point tiga ini telah didapatkan solusi berupa desain mesin yang tahan terhadap rentang suhu tinggi. Sehingga, didapatkan hasil perakitan keseluruhan bentuk mesin terdiri dari bahan metal baja, bagian casing mesin, penutup mesin, pintu mesin, ruang pengapian mesin, maupun rak penempatan baglog yang berada dalam ruangan mesin juga terbuat dari bahan baja. Hasil pemilihan bahan baja pada perkitan mesin steamer ini dapat mengisolasi uap udara panas secara maksimum guna mempersingkat proses sterilisasi dan menghindari kejadian ledakan mesin akibat mudah memuainya bahan mesin.

Sedangkan permasalahan poin empat yaitu untuk meningkatkan kuantitas dan kapasitas produksi jamur tiram, telah didapatkan solusi berupa hasil desain mesin berbentuk persegi dengan pengisian kapasitas 500 baglog. Hasil desain mesin ini diharapkan kapasitas produksi baglog yang semula hanya 100 baglog sekarang meningkat menjadi lima kali lipat yaitu 500 baglog dalam sekali proses sterilisasi baglog.

Berdasarkan hasil analisis dan pembahasan setiap solusi permasalan yang dihadapi kelompok petani budidaya jamur tiram Desa Duyung. Telah dilakukan koordinasi kegiatan dengan pihak mitra untuk mempersiapkan pelatihan dan demonstrasi penggunaan mesin steamer seperti yang ditunjukkan pada Gambar 5. Kegiatan persiapan demonstrasi penggunaan mesin steamer dipimpin langsung oleh ketua tim pengabdi. Kegiatan ini bertujuan untuk memberdayakan peran serta mitra 
dalam pelaksanaan kegitan demontrasi, menyediakan tempat dan perlengkapan penunjang kegiatan.

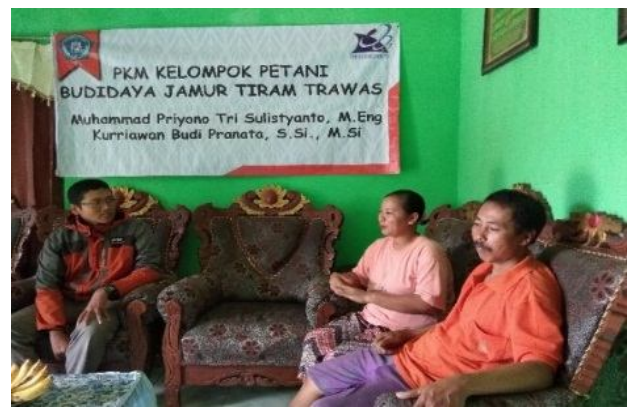

Gambar 5: Koordinasi kegiatan sebelum dilakukan demonstrasi plot (DEMPLOT) penggunaan mesin Steamer

Berdasarkan Gambar 5, telah didapatkan hasil kegiatan koordinasi berupa penyesuaian jadwal pengiriman mesin, pelaksanaan kegiatan dan mempersiapkan tempat pelaksanaan kegitan demonstrasi. Tindak lanjut hasil koordinasi tersebut, dilakukan kegiatan demonstrasi penggunaan mesin steamer seperti yang ditunjukkan pada Gambar 6.

Pada Gambar 6, mesin steamer yang dibuat ini menggunakan prinsip isolasi uap udara yang dihasilkan dari pemansan air yang diletakkan pada bagian atas ruang pengapian lantai mesin. Sehingga pengaturan volume air dan level ketinggian air pemanas sangat berperan penting terhadap kecepatan pembentukan uap udara didalam ruangan mesin steamer dan menghindari pemborosan penggunaan sumber energy panas yang digunakan.

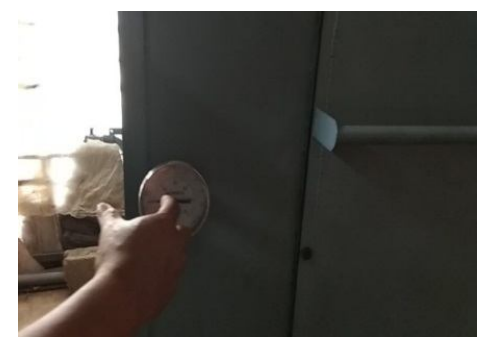

Gambar 6: Pelatihan dan demonstrasi pemahaman keselamatan kerja saat mesin beroperasi

Berdasarkan serangkaian kegiatan demonstrasi yang ditunjukkan pada Gambar 6, didapatkan hasil review kegiatan demostrasi penggunaan mesin steamer meliputi:

1. Menjelaskan beserta demonstrasi cara pembacaan alat ukur monitoring suhu, cara proses kalibrasi sensor suhu, dan cara setting set point offset nul dengan suhu lingkungan mesin.

2. Menjelaskan beserta demonstrasi kalibrasi level ketinggian air pemanasan secara akurat guna menghindari pemborosan penggunaan sumber energi panas yang digunakan.

3. Demonstrasi peralihan sumber pengapian mesin Steamer dari menggunakan sumber panas gas elpiji menjadi sumber panas kayu bakar.

4. Menjelaskan beserta demonstrasi penempatan posisi baglog saat berada didalam ruang mesin steamer agar uap udara panas dapat terdistribusi merata.

Gambar 7 merupakan tindak lanjut setelah dilakukan kegiatan demontrasi penggunaan mesin steamer yaitu melakukan kegiatan kunjungan, wawancara dan tanya jawab terkait kendala-kendala yang dialami pihak mitra pada saat proses penggunaan 
mesin baik secara teknis maupun secara teoritis.

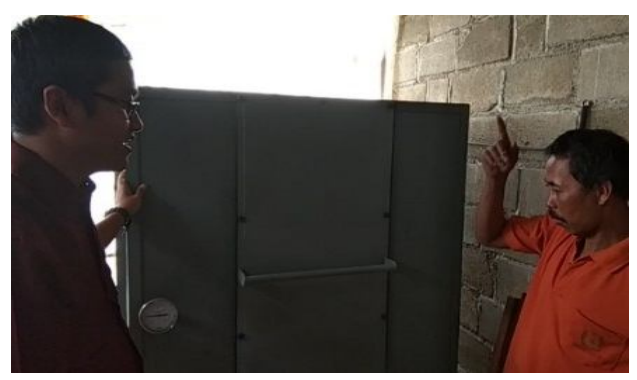

Gambar 7: Monev efektifitas penggunaan mesin

Berdasarkan hasil yang ditunjukkan pada Gambar 7, telah didapatkan hasil rangkuman kegiatan monitoring meliputi:

1. Mitra merasa puas dengan adanya mesin steamer yang telah dibuat, rentang waktu strelisasi baglog berkurang hingga 7 jam, yang awalnya proses strilisasi dengan kapasitas 100 baglog membutuhkan waktu 15 jam sekarang hanya ditempuh waktu 8 jam dengan kapasitas 500 baglog.

2. Sejalan dengan itu, kapasitas baglog menjadi meningkat 5 kali lipat dalam satu kali proses sterilisasi.

3. Mitra merasa nyaman dalam bekerja karena tingkat resiko kekhawatiran ledakan mesin telah hilang.

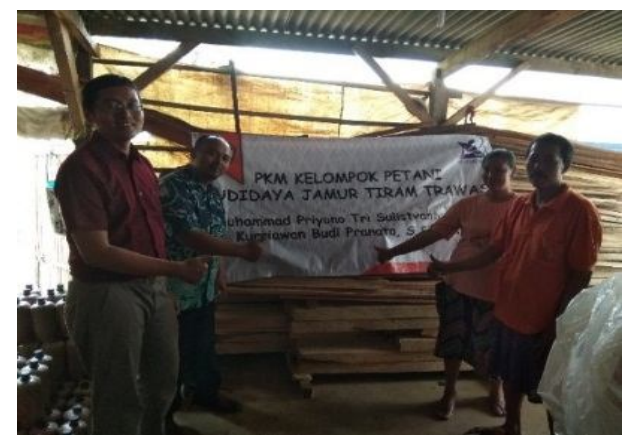

Gambar 8. Kegiatan serah terima mesin Steamer kepada Mitra
Sejalan dengan serangkaian kegiatan evaluasi dan monitoring, tim pengabdi melanjutkan dengan kegiatan serah terima mesin steamer Hasil dari kegiatan tersebut seperti yang ditunjukkan pada Gambar 8 .

Harapan dari serangkain hasil kegiatan pengabdian masyarakat ini sebagai salah satu upaya untuk menghilangkan asumsi tentang resiko baik secara ekonomi dan keselamatan kerja dalam menjalankan wirausaha budidaya jamur tiram. Sehingga kedepannya dari hasil kegiatan ini dapat memunculkan wirausahawan baru tentang budidaya jamur tiram sebagai penunjang potensi pariwisata di wilayah kecamatan Trawas dan penguatan asupan gizi produk pangan nasional.

\section{SIMPULAN}

Berdasarkan hasil egiatan pengabdian masyrakat yang dilakukan dan diterapkan pada kelompok petani budidaya jamur tiram di Desa Duyung Kecamatan Trawas Kabupaten Mojokerto didapatkan kesimpulan sebagai berikut: (1) Peningkatan pengetahuan sterilisasi baglog dapat dilakukan melalui transfer teknologi mekanis pada pembuatan mesin steamer yang standart. (2) Penurunan tingkat kecelakaan kerja pada saat sterilisasi baglog dapat diredam melalui pemasangan alat monitoring suhu ruangan mesin steamer. (3) Sterilisasi baglog dapat dipercepat berdasarkan desain mesin steamer yang benar-benar tertutup rapat guna mengisolasi uap udara secara maksimum. (4) Jika proses sterilisasi baglog dilakukan sesuai standart. Potensi terjadinya gagal panen dan resiko kerugian dapat ditekan yang berakibat terhadap peningkatan kuantitas dan kapasitas produksi jamur tiram. 
Muhammad Priyono Tri Sulistyanto, dkk. Pemberdayaan Kelompok Petani...

\begin{abstract}
Rekomendasi langkah selanjutnya dari hasil kegiatan masyarakat ini berupa transfer teknologi pengemasan jamur tiram, mengingat jamur tiram adalah produk pangan yang bersifat perishable (mudah rusak) terhadap waktu dan faktor mekanik. Hal ini perlu direkomendasikan untuk memperpanjang siklus hidup jamur saat proses pemasaran yang membutuhkan waktu tempuh pengiriman dalam orde hari atau bahkan beberapa minggu.
\end{abstract}

\section{UCAPAN TERIMA KASIH}

Kegiatan pengabdian ini telah didanai oleh Direktorat Riset dan Pengabdian Masyarakat Direktorat Jenderal Penguatan Riset dan Pengembangan Kementerian Riset, Teknologi, dan Pendidikan Tinggi melalui skim pengabdian hibah Program Kemitraan Masyarakat pendanaan tahun 2017 dengan pelaksanaan tahun 2018.

Tim pengabdi mengucapkan terima kasih kepada Lembaga Penelitian dan Pengabdian kepada Masyarakat Universitas Kanjuruhan Malang yang telah banyak membantu dan memotivasi pelaksanaan kegiatan ini sehingga bisa terlaksana dengan sukses.

\section{DAFTAR PUSTAKA}

Sutarja. 2010. Produksi Jamur Tiram (Pleourotus ostreatus) Pada Media Campuran Serbuk Gergaji dengan Berbagai Komposisi Tepung Jagung dan Bekatul. Universitas Sebelas Maret, Surakarta.
Suriawiria, U. 2002. Budidaya Jamur Tiram. Yayasan Kanisius. Yogyakarta

Sucipto, Edi (2015) Analisis pengaruh kekuasaan, kemitraan dan kewirausahaan terhadap kinerja bisnis jamur tiram putih (Pleurotus ostreatus) di kabupaten jember. Masters thesis, Institut Pertanian Bogor.

Jenisa, Devy, (2018) Analisis Kelayakan Finansial Dan Risiko Usaha Budidaya Jamur Tiram Di Provinsi Lampung, Skripsi, Universitas Lampung.

Penduduk - Kabupaten Mojokerto (2017). Jumlah Penduduk Kabupaten Mojokerto Menurut Jenis Kelamin Per Kecamatan Bulan Desember Tahun 2017. [Internet cited 20185 September]. Available form: http://www.mojokertokab.go.id/t hm/v1/?vi=penduduk. Diakses pada 5 September 2018.

Perda Nomor 8 Tahun 2011 tentang RPJMDKab. Mojokerto 2011, [Internet]. 2011 [cited 201727 Mei]; Available from: bappeda.mojokertokab.go.id/upl $\mathrm{oad} / \mathrm{ca} 86 \mathrm{c} 4$ eeef78a414bbfa5d7b 8309553b.pdf.

Pranata, Kurriawan B. Ghufron, M. Sulistyanto, M. P. T. 2018, "Peningkatan Produksi dan Kualitas Produk Camilan Keripik Ketela di Kec. Trawas, Kab. Mojokerto" Journal of Innovation And Applied Technology 4(1). 